An ESRC Research Group

Global Poveriy Research Group

\title{
Political Entrepreneurs or Development Agents: An NGO's tale of resistance and acquiescence in Madhya Pradesh, India
}

\section{GPRG-WPS-024}

\section{Vasudha Chhotray}

\section{Global Poverty Research Group}

Website: http://www.gprg.org/

The support of the Economic and Social Research Council (ESRC) is gratefully acknowledged. The work was presented at the ESRC Global Poverty Research

Group /IDPM conference on 'Reclaiming Development? Assessing the

Contribution of Non-Governmental Organisations to Development Alternatives', University of Manchester, UK, June 2005. 


\title{
Political Entrepreneurs or Development Agents: An NGO's tale of resistance and acquiescence in Madhya Pradesh, India
}

July 2005

Vasudha Chhotray, ESRC Postdoctoral Fellow, Institute for Political and Economic Governance, University of Manchester, UK. Email: vasudha.chhotray@manchester.ac.uk

\begin{abstract}
NGOs have been lauded both for being political entrepreneurs- facilitators of transformative politics- and also development agents- implementers of participatory development. However, not many believe that NGOs can successfully combine both these roles. This view arises from a larger cynicism of the development machinery that constantly strives to exclude 'politics'. In India too, NGO-state relationships affirm that politically confrontationist NGOs have frequently been oppressed. This article presents a case study of an NGO in a central Indian state that, over an entire decade, was able to combine development work regarded as legitimate by the state with practices resisting state action in development. It demonstrates that the 'depoliticisation' of development is not always a successful state project with predictable consequences. Moreover, the $N G O$ 's seemingly dual stance was itself unreal, as resistance and acquiescence were interwoven with one another in subtle ways. The article rejects familiar binaries deployed to study NGOs, i.e. of state-civil society or mainstream-alternative development, and focuses instead on key junctures in the NGO's life history. It concludes that NGOs, operating within appropriate political conditions can be both political entrepreneurs and development agents, and indeed, this synthesis holds the key to their power.
\end{abstract}

\section{Introduction}

NGOs, the world over, have been regarded positively both for their capacities as 'political entrepreneurs' and 'development agents', but there is growing cynicism in their abilities to combine these two roles. As political entrepreneurs, NGOs have been known to act as catalysts of radical change, through their association with grassroots struggle in various forms. As development agents, NGOs have increasingly become key partners both of governments and donor agencies in implementing development programmes, particularly those of a participatory orientation. The definitive mainstreaming of participatory development during the last decade has accompanied growing pressures on NGOs, many of which may have started out as small and informal cadre based organisations, to compete for development funds, formalise their organisational structures and 'scale up' their work. All this seems to have compromised the inclination and ability of NGOs devoted to development, to engage in acts that are radically transformative. 
In fact, such cynicism afflicts development in general, perceived as an activity or set of relations that is divorced of 'politics'. This understanding is of politics with a capital 'P', as the 'discourse and struggle over the organisation of human possibilities' (Held 1984: 1), rather than the entire range of politics with a small 'p', from arbitrary interest seeking to organised electoral party politics, all of which regularly mediate development. Development outcomes therefore have frequently been proved to be conservative and preserving of status quo. The definition of what legitimately counts as 'development' by the state, through the use of law, and by the institutions of international development cooperation, through the general production of policy discourse, seems to be fundamental not only to development outcomes, but also to development processes, and the interactions between a whole host of governmental and non-governmental actors. The many guises in which the development machinery defines and excludes politics have been conceptualised as 'depoliticisation' in academic parlance (Ferguson 1990, Harriss 2001, Kamat 2002).

For NGOs, the problems of pursuing development that internalises politics as a radically transformative process are manifold. NGOs, notwithstanding the staggering diversity of organisations that comprise this category, are by no means exclusive of the state. They operate within its laws and are dependent upon its resources. The equation of NGOs with 'civil society', especially by donors motivated to aid processes of democratisation and participatory development, is unhelpful. Not only does such a tendency disregard the profound interrelationships between state and civil society, especially in the developing world (Kaviraj and Khilnani 2001), it has actually been known to 'undermine the formation of civil society' due to the 'bureaucratic logic of international development that funds NGOs regardless of their capability of bringing about democratic change' (Igoe 2003: 881). Moreover, the collapsing boundaries between 'mainstream' and 'alternative' development imply that to weigh NGOs' performance against a scale measuring 'alternative' development will probably lead to disappointment, and not much else (Pieterse 1998).

These trends point to the analytical difficulties of studying NGOs. In particular, it is difficult to appreciate the potential for change available to NGOs by their unique positioning in the interface between governments at different levels (both elected representatives and bureaucrats), local communities and foreign donors. It is my purpose here to argue that a dichotomy between the roles of NGOs as political entrepreneurs and development agents seriously limits the consideration of such potential. In this article, I will present case study evidence of an NGO in a 
central Indian state, Madhya Pradesh, to argue that NGOs need not, indeed cannot be, either political entrepreneurs or development agents. The article will show how, over an entire decade, this NGO has been able to combine development work regarded as legitimate by the state with practices resisting state action in development in general. In the process, it will demonstrate how and why the 'depoliticisation' of development is not always a successful state project with predictable consequences. The article will reveal that the NGO's seemingly dual stance was itself unreal, as resistance and acquiescence were interwoven with one another in subtle ways. In this analysis, I will avoid the familiar dichotomies of state-civil society and mainstream-alternative development. I will focus instead on the factors that constituted key junctures in the NGO's life history- of composition, location, legislation, organisational interrelationships and politics- and contributed to its local power and effectiveness. The article will conclude with general implications for the nature of as also limits to NGO power.

\section{The making of an NGO}

In India, 'NGO' is catch-all term that does not capture the wide range of voluntary initiatives that have existed since independence. The proliferation and composition of the 'NGO universe' in India has been competently described elsewhere (Garain 1994, Sen 1999, Kamat 2002). Two aspects of the evolution of NGOs in India are relevant for this narrative. One, following the highly iniquitous consequences of the 'Green' (for irrigated agriculture) and 'White' (for milk production and marketing) revolutions in the 1970s, Naxalites, other Maoists groups and socialist activists of the 'Sarvodaya' land redistribution movement, engendered radical outbursts to highlight the plight of the poor and landless. They were suppressed indiscriminately, most famously during Mrs Gandhi's national emergency of 1975. Two, in subsequent years, the Janata Government, backed by Sarvodaya workers, was sympathetic to 'voluntary' work and stepped up state technical and financial assistance to it (notably through the establishment of CAPARTCouncil for Promotion of Rural Arts and Technology), and a number of NGOs mushroomed in response. With the sweeping endorsement of participatory development by international development organisations in the late 1980s and 1990s, NGOs found explicit recognition in state development plans and policies.

NGOs in India continue to share a spectrum of relationships with state institutions and actors at different levels, ranging from different shades of cooperation to antagonism. However, there seem to be two broad strands even within this range. NGO activity in development and relief work has generally been received favourably by the state, and indeed explicitly encouraged. But 
simultaneously, NGOs that have adopted a politically confrontationist stand against state policies, institutions or actors, have typically been disassociated with the state's development agenda, and occasionally been repressed. The $7^{\text {th }}$ plan document of the Government of India even defined NGOs as "politically neutral development organisations that would help the government in its rural development programmes' (cited in Sen 1999: 342). It is in the context of this brief history that I now proceed to recount my tale.

The organisation that forms the subject of my study started its association with Bagli tehsil (block) in Dewas district in south-west Madhya Pradesh in $1992^{1}$. Dewas is a dryland district, with low and undependable rainfall, but contains striking regional disparities. The Narmada valley divides the district into two parts: ghaat upar (in Hindi, meaning the area above), comprising the fertile Malwa uplands, benefits from a long tradition of irrigated cultivation and industrialisation, and is generally characterised as more prosperous economically than the area below, known correspondingly as ghaat-neeche. Bagli tehsil lies in the ghaat-neeche part of Dewas district, and suffers a long history of economic marginalisation and resource degradation. Moreover, the ghaat-upar part is also the political nucleus of the district: both geographically, with the location of the district headquarters and sociologically, with the domination of non-tribal upper castes in district and state level politics. The ghaat-neeche part, comprising Bagli tehsil, has large tribal pockets. Here the Bhil and Bhilala tribes (originally residents of neighbouring Dhar district that migrated to Dewas in the early $20^{\text {th }}$ century, presumably to occupy large tracts of cleared forestland) are interspersed with a large non-tribal majority, and suffer exploitation at their hands ${ }^{2}$. Most tribals in this region have small plots of land (given by the government at the turn of the century), but practise rainfed agriculture, which is insufficient to meet their family needs even. They face exploitation through unfair wage labour on the lands of their non-tribal neighbours. They have also succumbed to a tortuous routine of annual migration to the Malwa lands, where unlike ghaat-neeche villages, irrigated cultivation continues for the winter (rabi) crop as well as during the summer.

\footnotetext{
${ }^{1}$ Fieldwork methodology is principally qualitative spanning two months spent with this NGO in Dewas in 2000. I conducted semi-structured and unstructured interviews with the NGO's founding members as well as its 'grassroots' workers, district officials, regional politicians, and unstructured interviews and group discussions for triangulation with a wide range of individuals in its principal village of activity. Given that the NGO started work in Bagli in 1992, oral histories constituted a significant research tool. I also examined documents produced by the NGO and local newspaper reports.

${ }_{2}^{2}$ At least 14 villages in the 97-village belt in ghaat-neeche are entirely non-tribal (Bagli Census Records 1991).
} 
The choice of Bagli as an area of work was a considered one. None of the organisation's eight founding members had resided or worked in this tehsil, or anywhere in Dewas district, prior to their arrival here in 1992. They were a group of friends who had met at the Jawahar Lal Nehru University in Delhi, known for its left-oriented political thinking. All group members are from 'high castes', most come from middle class families and a few from more affluent backgrounds with important political connections. They are educated and English speaking, while conversant in Hindi, the main regional language. Nearly all had fulltime academic careers before they decided to start work that allowed them to engage more directly in pursuit of their beliefs. The social backgrounds of group members would prove to be consequential in course of their interactions with the local people of Bagli as with government functionaries at senior levels.

The group sought to work in Bagli because it represented long periods of political and economic marginalisation, which had in turn produced official disinterest in the region and simultaneously, the marked absence of popular mobilisation amongst its marginalised tribal peoples. Group members wanted to build a 'peoples' organisation' that would engage in grassroots work and advocacy" $^{3}$. The formation thus, of a 'critical mass within policy making, so that marginalised tribal areas would get the benefit of increased state intervention and public investment' was central to the stated discourse of the group, and of the organisation it eventually formed. The group also knew that it specifically wanted to promote local natural resource management, which it believed would offer a lasting solution to resource poverty, a chronic problem in tribal areas. Its overarching aim would be to increase local awareness of the laws of the state and constitutionally prescribed rights. In terms of ideology, the group professed an explicit belief in development, and equally importantly, in the state as the principal guarantor of rights. Theirs was an ideology of 'positive engagement', with the state, its policies, institutions and actors ${ }^{4}$. From this point of view, Bagli was as appropriate a destination, as it was ironical. Its long history of marginalisation was in keeping with the group's objectives, but also, the nascent interest of the group would annoy all existing local stakeholders. Not entirely aware of what was to follow, the group registered itself as an NGO, and set up a makeshift office in Bagli town, using the personal savings of its members. The NGO was called Samaj Pragati Sahyog (in Hindi, meaning 'Support for Social Progress'), henceforth referred to as SPS.

\section{Acquaintance with Neelpura village: Setting up home base}

\footnotetext{
${ }^{3}$ Interview with a group member, Bagli, 2000

4 'We do not regard Naxalism to be a way forward', said a prominent member denouncing anti-state activism that in his opinion is easier than 'serious development work' (Interview, 2000, Bagli).
} 
Local curiosity about the newly formed SPS only increased when group members attempted to acquaint themselves with Bagli and the ghaat-neeche villages. Group members recounted how local officials and politicians based in Bagli, a small market town, were distinctly unfriendly. According to the group, they were most perplexed because SPS, unlike other NGOs in the district, was not there to implement any particular development project. The lack of a clearly spelt out role also aroused incomprehension on the part of villagers during SPS's initial forays, on motorcycles, into the ghaat-neeche village belt. Soon enough, group members decided to concentrate their attention on one small village, conveniently located close to the main road, and comprising almost entirely of the Bhilala and Korku tribes, a village called Neelpura ${ }^{5}$. This decision may have been motivated by convenience at the time, but quickly became vital to the identity of SPS in the region, and initially, to its very survival.

Moreover, the socio-economic characteristics of Neelpura closely matched SPS's idea of a 'base village' in keeping with its stated objectives. It is almost uniformly poor, with most tribals owning lands between 1 and 3 acres in size, which too are dry. A handful of farmers own more than 6 acres and only 3 out of the 100 odd households in the village are presently landless. This relatively egalitarian pattern of land ownership follows from government distribution of similar land plots to the new migrants, nearly a century ago. Neelpura is also relatively homogenous socially, since caste-based social polarisation is conspicuously missing in this predominantly tribal village.

SPS's quest for local contacts within Neelpura to facilitate initial dialogues soon revealed the nature of power relationships in this seemingly unstratified village. Mahbub Khan, a Muslim landowner with more than 30 acres of land (of which 10 were irrigated) was economically dominant, his social clout evident in his near exclusive engagement of hired labour and cultivation of a second irrigated crop. Politically however, Mahbub remained reclusive, and a Bhilala family that had long performed functions of tax collection and dispute resolution, assumed the title of Patel or village headman. The Patels were respected within the village, and the family's patriarch traditionally acted as the sarpanch of the village panchayat ${ }^{6}$, which in turn was practically defunct. However, with the increasing emphasis on decentralisation to panchayats, leading up to the $73^{\text {rd }}$ constitutional amendment of 1993 (which granted constitutional recognition to panchayat bodies for the first time), the state government of Madhya

\footnotetext{
${ }^{5}$ The village and all individuals associated with it have been given proxy names to protect anonymity.

${ }^{6}$ Panchayats are three tier locally elected bodies at the district, block and village levels.
} 
Pradesh took steps to reorganise panchayats and galvanise their functioning. As a result of such reorganisation in 1990, Neelpura was (unfortunately) clubbed with its large non-tribal neighbour Bhimpura, and reduced to a hamlet within Bhimpura panchayat. Lakhan Singh ${ }^{7}$, a landless though politically connected individual from Neelpura became sarpanch. Singh was friendly with other sarpanches in ghaat-neeche and with politicians at the Bagli tehsil office. As SPS discovered through their landlords in Bagli, Singh harboured ambitions of contesting elections to the Janpad (block) panchayat. Of all three 'power holders', he was the friendliest to group members, offering them hospitality during their frequent visits, perhaps to further his political ambition (SPS's version) or because he was impressed with SPS's promises of doing 'good work' for the village (Singh's version).

Singh's perception of SPS's motives was not inaccurate, since SPS's members repeatedly asked villagers to tell them of their problems. In doing so, they created expectations of solutions, and soon enough, the NGO effortlessly slid into its intended role of 'developer'. It earned greater familiarity in Neelpura, whose residents began referring to it as sanstha (Hindi for organisation). As the scarcity of water was the key problem, SPS offered to dig wells on the private lands of people, and raise water conservation structures like earthen bunds and field ponds. Water conservation in these dryland areas is a significant development objective of the state, and SPS soon received funds from the Government of India under different central government schemes for the purpose ${ }^{8}$. Although sceptical of SPS's offers of 'free wells' initially (due to bitter memories of a loan scheme in the 1970s that had led to government 'harassment' for repayment), most people in the village soon agreed to have their old wells deepened or new wells dug.

These development activities by SPS constituted an important moment in its relationship with the people of Neelpura. Working on the individual lands of people in this small village allowed SPS to come into close contact with their families. It was not long before group members were engaged in extremely personal acts of help to villagers, such as taking an infirm old man to the local hospital if necessary. Conversely, most people in the village gradually became dependent on SPS, with continuous expectations of help and support. Some people also felt left out and bitter with SPS, when they discovered that the well digging projects had finished, and new wells could only be provided for a payment. By 1995, SPS had come a long way. It had a base village from

\footnotetext{
${ }^{7}$ Tribals throughout the ghaat-neeche region have started using non-tribal names, a phenomenon that speaks of the increasing pressures of social mobilisation.

${ }^{8}$ The Tribal Development Department, Department of Science and Technology and CAPART sanctioned money to SPS for well-digging and other related activities under different schemes.
} 
where to begin its task of building a 'peoples organisation', and it was also surely acquiring a definite role for itself in relation to development work in the area. As evident in its well-digging initiative, SPS also had no qualms in extending a highly 'individualised' approach to development through beneficiary creation ${ }^{9}$. And as the following events will illustrate, it did not view this approach as necessarily antithetical to the formation of collective solidarities, as has been suggested by some authors (Kamat 2002).

\section{A troubled period: Confrontation, resistance and development}

During its implementation of the well digging and water conservation projects in Neelpura, SPS stumbled upon two types of exploitative practices in the region. These revealed the nexus of domination by anti-tribal forces in the ghaat-neeche area. It detected that the overall wage structure, especially for public works, in this tribal belt was not in keeping with the equal minimum wage laws of the country enacted in 1948. Both large farmers and panchayat sarpanches (acting through contractors), who engaged labourers for the execution of construction works, perpetuated this injustice. SPS also discovered that land records of poor tribals throughout the ghaat-neeche had not been updated in accordance with the Madhya Pradesh Land Revenue Code of 1950, and essential information, such as correct rates for land transactions, was being kept out of their bounds by the local revenue bureaucracy. This included both the village patwari as well as the sub-district magistrate of the revenue division, who stood to gain monetarily from such malpractices ${ }^{10}$. Emboldened by the absence of challenge, these junior state officials had also acquired near autocratic status locally.

Despite its infancy in the area and the nature of the backlash any protest would invite, SPS chose to confront the perpetrators of such exploitation. First of all, it insisted on paying equal minimum wages to all labourers hired on its development projects, an unprecedented act that upset old wage relations in the area. In one stroke, SPS had made enemies of large farmers, sarpanches and contractors in ghaat-neeche. Although some sarpanches like Lakhan Singh in Neelpura were tribal, this was predominantly an anti-tribal coalition. A minor though not insignificant detail is the alienation that SPS suffered in its own little base, as it had angered its principal ally, Singh, as also Khan, the richest landowner. Even as these developments brought SPS into public scrutiny beyond ghaat-neeche, it went further and contacted the District Collector with a proposal to

\footnotetext{
${ }^{9}$ A member of SPS defended the well-digging initiative as necessary to remedy the 'severe under-utilisation' of ground water reserves in the village, and also to elicit their interest in natural resource utilisation. SPS admits however that the issue of ground water extraction is a complex one, and also that they have 'no right to stop people who have never tapped their existing resources optimally, from doing so now'.

${ }^{10}$ They sold land revenue books worth five rupees at five thousand rupees per copy!
} 
organise a 'land records camp' in order to rectify the appalling records situation. The senior most official of the district lent her support to SPS, and in January 2005, such a camp was organised in Neelpura village. It was a huge success, with more than 13,000 tribals travelling far to attend, and the district collectorate backed it with two additional camps.

The turn of events described here constituted a striking juncture in the evolution of this NGO. It marked the beginning of antagonistic relationships with junior officials (like the sub-divisional magistrate), whose vested interests suffered following SPS's intervention, but more favourable relationships with senior district and state level officials, who had no similar interests at stake. Moreover, SPS communicated easily with elite and influential members of the Indian Administrative Service, due to the social mobility that an 'English' education and privileged upbringing can bring in India. While these constituted important explanations for events, the most important, in my reading, was SPS's successful emphasis on the idea of state as the guarantor of rights, and therefore of the need to uphold legislation that no civil servant could possibly disregard in public. In both its initiatives, of minimum wage and land records, SPS was not campaigning to change laws, but rather to uphold them. To this end, SPS had been true to its objective of increasing local awareness of constitutionally prescribed rights.

Moreover, without deviating from the legitimate framework of state laws, it had exposed the intricate politics of exploitation that impeded the development of the ghaat-neeche region (both within the ghaat-neeche and versus the ghaat-upar regions through the subordination of the tribal population). In doing so, it conveyed how regular development work mandated by the state rested on critical political issues like the disregard of law (that codifies important rights) and abuse of authority. And yet, following the contradictory nature of the state, there are simultaneously existing laws like the Charitable Trusts Act of 1950, which apply to voluntary organisations, and state that, 'The achievement of a political purpose, in the sense of arousing in the people the desire, and instilling into them an imperative need to demand changes in the structures of the administration and the mechanism by which they are governed...is not a charitable purpose as being one "for the advancement of any other object of general public utility within section 9(4) of the Act" ' (as cited in Kamat 2002: 56). This clearly illustrates the use of law by the state to act as an instrument of depoliticisation, and but for the fact that SPS had discovered malpractices in relation to existing law, it too may have been in trouble with its funding agencies, notably 
CAPART $^{11}$. Equally important was its location in ghaat-neeche, the site of subordinate politics within the district, as opposed to ghaat-upar, where SPS may have found it a lot harder to campaign for change. Greater political stakes embedded in the long history of non-tribal and upper caste domination would have meant lesser space for tolerance of opposition, a point admitted to both by SPS and district government officials whom I met.

However, even in ghaat-neeche, SPS experienced considerable resistance. A powerful sarpanch from a village neighbouring to Neelpura, took umbrage to the fact that SPS had initiated the deepening of the main tank there, on a show of written support by other members of the panchayat and ordinary residents, but without his 'permission'. He galvanised thirty other sarpanches (already seething with anger against the NGO) and with the help of the local Congress MLA (Member of Legislative Assembly), took a delegation to the Chief Minister (of the ruling Congress party at the time), to complain that the NGO was 'corrupt, it bypassed panchayats and misappropriated their money' and should be 'removed'. This reaction was interesting and a testimony to pro-panchayat decentralisation initiatives underway in Madhya Pradesh post the $73^{\text {rd }}$ constitutional amendment, which had greatly bolstered the confidence of sarpanches ${ }^{12}$. SPS reacted by pursuing a vigorous policy of image building as a transparent organisation that worked in popular interest. The local press further dramatised these unprecedented developments through sensational articles. The situation was ultimately resolved through the appointment of an 'inquiry committee' headed by the district level panchayat (a clever ploy by the state bureaucracy to assuage angry sarpanches). The committee however, following its investigations, acquitted SPS of the charges and commended it for its 'good work' during an assembly convened in Neelpura village.

SPS gained tremendously from public approval by the highest elected authority in the district. Its local opponents realised that 'the luxury of direct confrontation' against SPS was one that they could no longer afford (Scott 1990), although private confrontations between individual sarpanches and members of SPS ensued on a number of occasions. From being an 'outsider' to the region, SPS was clearly an ascendant power that rested on a successful strategy, both practical and discursive, of development, legality and positive engagement with the state. To this, SPS specifically included the element of dialogue with panchayat raj institutions, whose latent

\footnotetext{
${ }^{11}$ Kamat narrates how an organisation in Thane district in Maharashtra, while protesting against practices of bonded labour, was informed by CAPART, that 'as a development agency, it was illegal for them to undertake "political" activity (2002: 53).

${ }^{12}$ The Chief Minister at the time publicly demonstrated his support to sarpanches, such as by sitting amidst them in rallies.
} 
potential it may not have recognised when it first arrived, but now unmistakably knew. In no time, SPS's stated objectives included an explicit role of 'galvanizing the panchayat process' both for itself and other similar voluntary organisations as well ${ }^{13}$. At a time when the ruling Congress leadership in Madhya Pradesh was emphatic upon decentralisation to panchayats, SPS seemed to have stumbled upon the right language for creating necessary local institutional space.

\section{Formal agent of the state: Doing development daily}

Recognition from the state government came soon, and in the summer of 1995, SPS was invited by the Dewas district administration to become a Project Implementing Agency (PIA) for watershed development projects in the ghaat-neeche villages. The state government implements the Union Ministry of Rural Development's Watershed Development Programme, designed to regenerate rural livelihoods through soil and water conservation ${ }^{14}$. The programme adopts a decentralised administrative structure, and while the district is the principal nucleus of decisionmaking in terms of administrative procedures, government officers or NGOs appointed as PIAs are responsible for the implementation of individual micro-watershed projects. SPS had already been working for water conservation in Neelpura and its adjoining villages using government funds. It accepted the offer.

SPS's selection as a PIA for a state funded and managed development programme was particularly significant for two reasons. First, it showed that the NGO's resistance to certain types of state practices did not preclude its appointment as a formal agent of a premier state development programme. It showed that there were no definite boundaries between NGOs that implement development projects using government money and those that resist state practices. Second, it brought about the extension of the state's watershed development intervention to the impoverished and politically subordinate ghaat-neeche area in the very first year of the programme, even as the district administration experienced pressures for allocating watershed projects to electorally important villages in the ghaat-upar area ${ }^{15}$.

\footnotetext{
${ }^{13}$ Interview with the Secretary, SPS, Bagli, 2000

${ }^{14}$ The term 'watershed' above any point on a defined drainage channel is used to denote all the land and water areas that drain through that point, leading to the 'normalisation' of a 'micro-watershed' as a 'rational' unit of planning (Tideman 1998: 7).

${ }^{15}$ The first village to be 'awarded' a watershed project in Dewas district is economically prosperous, large and populous, all key ingredients of 'electoral capital'. It also has an independent panchayat, and has regularly been receiving generous shares of the discretionary funds available to Members of Parliament and Legislative Assembly.
} 
The selection of ghaat-neeche villages, and of SPS as PIA, highlights the presence of a distinct political process that translated popular mobilisation by an NGO into greater involvement with the state's development agenda. In this respect moreover, SPS's confrontationist trajectory exposed the limitations of the state's depoliticisation discourse by revealing the intricate connections between development and politics with a small 'p' (of vested interest seeking). But more importantly, its pro-active role as an agency of politics with a capital 'P', whereby it overturned unfair wage relations and updated land records, actually paved the way for a more substantial role in state-led development. Depoliticisation clearly, was not a 'successful' state project with predictable consequences, although the lack of success proved to be in the state's own interest. The marked improvement in condition of a large number of people in the ghaatneeche as a result of SPS led initiatives could only have restored their faith in a state, otherwise known to them mainly through its horrific acts of exploitation and abuse of authority.

As the PIA of Neelpura watershed project, SPS was in a vastly different position from other PIAs, as the village and its intra-personal dynamics were extremely familiar to it. The national watershed guidelines 1994 advocate the creation of non-elected community-based bodies or 'watershed committees' to facilitate participatory decision-making in projects and envision their formation through a consensual process in a public gathering a few meetings after the project commences. The guidelines also underplay the role of the PIA in influencing the constitution of the committee, projecting the entire process as a 'pristine' 'community-based' initiative. This notion itself is questionable, given the typically stratified composition of communities and the interactions between project staff and village elites that dominate committee formation and functioning (Chhotray 2004). But in the case of SPS and Neelpura, it was far from applicable. Moreover, SPS chose to have a clear say in the formation of the committee and as several group members reiterated, it was responsible for creating an 'effective cadre of leaders' that would be able to take 'contentious decisions that are inevitable in a land-based programme like watershed development'. The committee was formed and two prominent members of the Patel family, by now very friendly with SPS, became its chairman and secretary. Both Lakhan Singh and Mahbub Khan stayed away from these new developments.

The style of committee formation set the tone for a flexible and non-procedural interpretation of project management. In its daily administration of the watershed project, SPS tried to create a 
political culture of 'genuine devolution' and 'demystification' of technical project management ${ }^{16}$. It initiated an informal planning exercise in consultation with people in the village to decide upon the location and sequence of various types of project structures like earthen bunds, rock filled dams, check dams, and so forth. However, it was not rigid about adhering to the action plan at all $\operatorname{costs}^{17}$. SPS trained a few interested members of the committee to monitor works locally, measure and note works, handle project money, way wages, and maintain financial records which were later checked and aggregated at the NGO's office in Bagli. It similarly did not bother with procedures such as regular group meetings or recording minutes of committee meetings, maintaining energetically that the watershed project was being subject to the "natural processes of village level decision-making' with all its imperfections ${ }^{18}$. This together with the very visible transactions of the project in public sites within the village, such as engagement of labour, payment of wages and documentation of records, substantiated the NGO's discourse of fairness, transparency, accountability and decentralisation.

This discourse had an underbelly however, which was not quite as flattering. By the time the project was underway, there was a small constituency within Neelpura that thought SPS had deliberately adopted a divisive policy in the village in order to build a support base for itself. Many were disgruntled because SPS had gradually begun the process of employing some youth from the village, those it knew and trusted, as 'grassroots workers'. To begin with, these same individuals were active in the watershed committee; indeed, the watershed project had been instrumental in strengthening their association with the NGO. They received regular monthly salaries, a fact deeply resented by many in this poor village, where cash incomes through wage labour and marginal sales of agricultural produce are meagre. Also, this disgruntled group predictably included Mahbub Khan and Lakhan Singh, who felt alienated within a setting they had previously dominated. Their perceptions however provided interesting insights into the NGO's working, not otherwise obtained through interviews with its own personnel. Mahbub remarked how the sanstha was 'manipulating support for itself by offering jobs to persons from large families on its many development programmes in neighbouring villages ${ }^{19}$. While the information contained here may not have been entirely correct (the extent of intentionality on the

\footnotetext{
${ }^{16}$ Expressions used by the Secretary, SPS.

${ }^{17}$ For instance, when several farmers expressed apprehensions about constructing earthen bunds on their lands, neither did it coerce them in order to meet physical targets, nor did it try to report completion of targets when they actually had not been met (formal compliance). It simply made certain changes to the order of works, and soon enough, it was able to acquire the permission of farmers for raising earthen bunds.

${ }^{18}$ Interview with the Secretary, SPS, Bagli, 2000

${ }^{19}$ Interview with Mahbub Khan, Neelpura, 2000
} 
NGO's part, as was being alleged, is difficult to verify), the perception that SPS was there to stay, and was slowing expanding its development activities in other ghaat-neeche villages was accurate. The physical embodiment of this came in 1998, when SPS received a large grant from CAPART to establish a 'field station' about a kilometre away from Neelpura. SPS has named the centre after Baba Amte, a respected social worker amongst poor people in the tribal areas of Madhya Pradesh.

SPS's growing physical presence no doubt had an increasing impact on the formation of local consciousness and the mobilisation of local identities. The watershed committee is a good example, as there was a clear employer-employee dimension to the interactions between SPS and local youth managing project works. SPS defends this on the grounds that there is an administrative budget for personnel assisting the PIA, for a 'Watershed Development Team' (WDT), which it utilises not by engaging 'outsiders' who may be technically qualified, but instead by training people locally, and collapsing the roles of the WDT and the committee. There were other cases too, which indicated growing allegiances to and against the $\mathrm{NGO}$, and not merely in Neelpura. The sarpanch of the Bhimpura-Neelpura panchayat, a rich non-tribal landlord from Bhimpura, who became sarpanch in the panchayat elections of 2000, was one such opponent who resisted the NGO's presence. Many in Neelpura also had misgivings about SPS trying to influence the outcome of the 2000 panchayat election (the most recent to my fieldwork trip) by propping up favoured candidates ${ }^{20}$.

Although specific in nature, these issues embodied wider problems afflicting NGOs that attempt to work at the grassroots. In relation to a 'successful' participatory mapping exercise conducted in Bali, Indonesia, Carrol Warren writes that 'leadership and the relationship of the volunteer group to their communities were among the problematic issues that emerged' (2005: 61). While normally impregnable in their mutual solidarity, I was able to observe some difference in the individual approaches of SPS's core members in dealing with local opposition. Even as some felt that it was within their remit, as PIA of the watershed project, to advise their staff and 'tell them what to do and not to do', others felt it was best to leave the village alone to deal with its own internal matters, intervening only in extreme situations. Nevertheless, in an overall sense, SPS's evolving strategy for addressing local conflict, which had initially been explicitly

${ }^{20}$ There was a temporary escalation of the issue as the newly elected sarpanch trying to capitalise on existing discontent against SPS. With the help of an 'ex-employee' of the NGO, he wrote to the funders of a housing programme implemented by SPS, that the NGO had been campaigning for a certain candidate by promising 'houses' in lieu of votes. The NGO responded to the funders with systematic evidence disproving the allegations and the matter was resolved. 
confrontationist, gradually gave way to a more sanguine discourse of 'partnership' with the panchayats, so that individual opponents like the new Bhimpura sarpanch could appear to stand isolated in their bickering. In a manner strangely similar to the influential institutions of international development cooperation, SPS's new and positive message of partnership reeked of a rosy confidence that only secure power holders can afford.

\section{Common property resource agreement: Using law to effect local rights within a project framework}

One case of explicit intervention by SPS in its capacity as PIA of Neelpura watershed project merits special discussion, for it reveals a remarkable act of political entrepreneurship to facilitate material and symbolic upturning of local power relations within the legitimate project framework. This involved rectifying a highly inequitable arrangement of access to a naala or stream of water, which flows down through the heart of village lands and is the only common water body in Neelpura. SPS was well aware that the use of this naala had been improperly appropriated by a small group of upstream farmers, Mahbub Khan in particular, who drew waters continuously through underground channels and daringly, through electric pump sets and diesel engines from the surface itself. Neelpura watershed has an underlying stratum of limestone in its lower reaches, and by the time the naala flows downstream, most of its water disappears underground. With a few farmers siphoning off waters upstream, those downstream had practically no access to running water or the opportunity to recharge their wells. Village livestock were the worst affected, since the naala ran dry after the rainy season.

Watershed project works included treatment of the naala's catchment, but SPS realised that under the existing arrangement, a rich, upstream minority would corner the likely benefits. It resolved not to go ahead with project activities until the arrangement had been overturned. It is clear that SPS was attempting to intervene in a highly contentious area, that other project agencies may have disregarded, but one that had actually been specified within its role as a PIA. The Ministry of Rural Development's policy framework emphasise common property resources and their proper consideration within the project action plan. Interpreting the powers accorded to it within this policy to the fullest, SPS went ahead and mobilised popular opinion in the village to formulate a collective agreement to regulate the use of naala waters. 139 farmers from Neelpura and some adjacent villages signed a written resolution, which in translation from Hindi reads as follows: 
It is decided by consent (sarvasammati) that nobody would ever draw water from the naala using a naarda. Those farmers who have wells will also not draw water from the naala using motors. Those farmers who do not have wells have agreed to draw water from the naala on a limited basis according to rules. After the water in the naala stops flowing, nobody would draw water from it, irrespective of whether they have wells or not. This water would be kept for cattle only. All villagers agree to this resolution (italics added).

Mahbub Khan protested vehemently, but under the weight of collective opinion and the NGO's vigilant stand, had to block the underground channels with cement along with the other farmers. Those who had water in their wells or lands on which wells could be dug, had to remove motors from the naala. SPS even constructed additional wells wherever necessary, free of any contributions from the farmer. The naala agreement was a matter of tremendous pride for SPS, and it mediated this to the last detail. In the initial days after the agreement, enthused villagers set up a system of rotation to watch the naala against possible violators at night. SPS claims that the agreement benefited everyone although those with lands upstream were at a greater advantage than the rest.

Mahbub Khan moved the court against the agreement, claiming 'easementary rights' over the naala, under the Indian Easementary Act of 1882. Its principal clause is that it allows a single user or group of users exclusive or predominant use over a village resource, on the basis of 'long use or prescription', on the grounds that this use has been peaceable, open and uninterrupted for at least 30 years, as an easement and over a resource that is not owned by anyone in particular. SPS fought back claiming that none of these grounds were valid. It offered convincing reasonsthe naala was actually owned by the government, which in 1993 had issued an order prohibiting villagers to refrain from its use, and Mahbub himself had claimed right of use for the last 17 years only. Mahbub was reprimanded for coming to court with 'unclean hands' and his appeal for 'easementary right' was struck down. This had the effect of upholding the naala agreement and effectively altered the local field of power. Mahbub Khan was dealt a clear blow, symbolic and material, and SPS once again established itself as pro-active agency of change.

The process of formulating this agreement and abiding by it introduced new political but also economic behaviour by farmers in Neelpura. The naala agreement proved to be central to the more equitable distribution of typical project benefits, allowing most farmers new opportunities for income generation. With more water flowing downstream than it did earlier, wells along the naala could be recharged for longer, leading to a noticeable increase in cropping area, both irrigated and unirrigated during the kharif (rainfed) and rabi (winter) seasons, as well as 
improved cropping practices such as intercropping that produced higher yields ${ }^{21}$. There was also an increase in double and multi-cropping. Whereas farmers earlier mainly raised coarse food crops like sorghum and inferior quality lentils, they now shifted to less coarse cereals like wheat and rice, and non-food crops like cotton and soybean, which could be easily marketed. SPS took particular care to introduce cotton varieties that are dryland resistant to ensure that small farmers with unirrigated lands were not excluded from the benefits of cotton cultivation. Perhaps most importantly, as a result of these changes, people from Neelpura have almost fully stopped migrating to the Malwa uplands during the long summer months. They work on their own fields, or as wage labourers in nearby lands, but also on project construction work in their village and remain hopeful of finding employment through the expanding activities of the NGO. The experience of concrete improvement in material conditions for the large majority of people fulfilled the cycle of expectations created when SPS had first started its work.

The naala episode also had an extremely positive impact on the working culture of panchayat institutions in the area. In a context where panchayats rarely convene gram sabhas, the BhimpuraNeelpura panchayat had passed a resolution legitimising the naala agreement in a sabha. Such practical endorsement of the panchayat forum came at a historic moment, in the aftermath of the $73^{\text {rd }}$ constitutional amendment, when the Madhya Pradesh state government had initiated propanchayat legislation, transferring powers and resources to panchayats as well as holding panchayat elections regularly for the first time since independence (see Behar 1999, 2001 and Behar and Kumar 2002 for details). In fact, taking the cue from the transparent modes of working encouraged by SPS in its watershed project activities, in the summer of 2000, a handful of panches from Neelpura challenged the rich, non-tribal sarpanch over misappropriation of panchayat funds. This action was unprecedented given the near autocratic conduct of sarpanches in the region, typically acting hands-in-glove with panchayat auditors (government employees) to manipulate panchayat records. I was witness to how the panches tried to gather information about their entitlements, from those associated with the watershed project in the village, and most of all from members of SPS in the Baba Amte Centre. Expectations of a confrontation between the panches and the sarpanch led to a massive turnout at the gram sabha, normally a farcical affair, and the panches demanded to see the panchayat's cash records. A heated argument ensued followed by the sarpanch and the auditor departing in a huff, and the panches were unable either to see the record or to recall the sarpanch through a mid-term resolution. Nevertheless, SPS looks

\footnotetext{
${ }^{21}$ See Appendix 1 for a table illustrating changes in land use in Neelpura watershed.
} 
upon this episode as the first sign of imminent, if not immediate, change in the regressive practices institutionalised in local panchayats.

\section{Scaling up development and scaling up politics}

Following from its experience in Neelpura, SPS has come a long way with a far more ambiguous vision of its own role in the ghaat-neeche region than a decade ago. It has energetically scaled up its development work, and from a couple of villages in Bagli tehsil in the mid-1990s, it now implements a range of development projects in 40 villages spread over 3 tehsils in Dewas and adjoining Khargone district with further plans for expansion. Its staff strength exceeds 100 and it has constructed new and impressive offices in Bagli. The main focus of its projects continues to be related to watershed development and drought proofing, and the funding agencies include the state government, CAPART (an old supporter of SPS) and more recently, the American India Foundation. It has also developed an 'Agricultural Programme' spread over 45 villages and an initiative for micro-finance through women's self-help groups is rapidly growing.

In all these projects, SPS is emphatic on transparency and has initiated regular public meetings or Jan-Sunvaayis (literally translated from Hindi as 'hearing of the people'). A typical Jan Sunvaayi involves a large public gathering in the village, attended by grassroots workers of SPS and frequently its founding members. They apprise the public of the project's progress, and also present the details of money being spent. Those present are encouraged to ask questions to SPS. Encouraged by its successes in Neelpura, SPS hopes that this exercise would promote a culture of accountability among local bodies in the region. This method of accountability is in tune with the idea of 'social audit' in the panchayat gram sabha promoted by the state, whereby an assembly of villagers would approve or disapprove of the panchayat's functioning on the basis of information presented in the sabha.

Not content with demonstration alone, SPS has adopted a much more pro-active strategy to contribute to the 'real' empowerment of panchayat institutions. It seeks to create a 'cadre of local leaders from amongst those who are committed to village development, but who are also from the poorer sections (tribals and women), to carry forward the panchayat process with systematic training, ${ }^{22}$. These activities go beyond the pall of 'regular' development project work and are visionary in a political sense. SPS views itself as an agent of decentralised development with a clear role to play in complementing state initiatives for decentralisation through panchayats. It

\footnotetext{
${ }^{22}$ Interview, Secretary, SPS, Bagli 2000
} 
intends to network with other grassroots organisations, similar to itself, and orient them to conduct training exercises for panchayats in their regions, and has already commenced work in this area in its Baba Amte Centre. This too has found abundant favour with the state government, which is officially committed to promoting panchayats.

While engaging in activities that are perceived favourably by state functionaries, SPS has also not shied away from issues that are politically contentious. It has continued to oppose the politics of state oppression of tribals, by allying itself with forces that have arisen to resist it. Bagli tehsil, with its forested areas, has been the site of exploitation of the tribal population by the Forest Department and more recently, their collective mobilisation against it through organisations called the Adivasi Morcha Sangathan and Adivasi Shakti Sangathan. The nadir of such exploitation came in March 2001, when the district administration authorised police firings upon tribals in a number of villages in Bagli, ostensibly to evict them from forest land which they had illegally occupied. The act was condemned widely in the popular press. According to the 'Friends of the River Narmada', a volunteer-based solidarity network, this attack was unjustified and fuelled by state animosity against the growing strength and local political influence of the tribal sangathans. SPS played an active part in investigating the firings, compiling a detailed report of the atrocities and supporting many tribal families that had been affected.

Unlike the earlier period in its history, when confrontation with established stakeholders was risky and support from certain quarters of the state administration untested, SPS was able to take a firm stand on critical issues without worrying about its own position. Over the decade, it had built up a popular following in the ghaat-neeche villages, exposed the vested interests of local opponents and marginalised them, built firm connections with the district and state level administrations and embedded itself firmly in state funded development activity. Thus, even as it championed politically thorny issues like tribal exploitation, it denounced radical politics that was de-linked from positive engagement with the state and its development agenda. Given that a large number of panchayats in the ghaat-neeche area are vying to collaborate with SPS for development work, it would appear that the NGO has successfully created a discourse that 'good economics could make excellent politics ${ }^{23}$.

\section{Hegemony or counter hegemony}

\footnotetext{
${ }^{23}$ A phrase used by a leading member of SPS in private email communication with the author.
} 
The narrative so far has described how counter-hegemonic initiatives against various forms of domination have underlined SPS's strategy, time and again since its arrival in the ghaat-neeche part of Bagli tehsil more than a decade ago. Through its struggle against exploitative wage practices, outdated land registrations and unfair appropriation of essential common property, SPS concretely overturned the fortunes of a dominant minority, and shattered even the "public transcript' of their hegemony ${ }^{24}$ (Scott 1990). In each case, the concerned actors suffered not just material loss, but also public shaming and a sharp curtailment in their previous authority.

Simultaneously however, SPS has rapidly gained in terms of local standing and prestige with a visible rise in material capacity. It is acutely aware of its new position and projects itself as the 'only agency, either governmental or non-governmental, that is talking about development ${ }^{25}$. This seeming appropriation of a legitimate mandate is not surprising; it closely follows from the NGO's iteration of positive ideas of the state, as a guarantor of rights (during its early confrontations) and subsequently, as a doer of development. While SPS may have resisted state structures or actors or processes, it never discredited the idea of the state as such, and has painstakingly moulded both its organisational practice and discourse to complement this stateidea $^{26}$. This has made it all the more difficult for local stakeholders to oppose SPS, which appears tall in its demonstrated conviction in all the 'good things' that the state might embody. This is drastically changing the politics of the 1990s, and even the Congress MLA who once facilitated a sarpanch-led petition to the Chief Minister for the ouster of the NGO, is seeking its support to bolster his constituency.

But what are the implications of the sort of power that this NGO is beginning to wield? I would argue that the latest phase in SPS's life history has witnessed the emergence of a new hegemonic position in ghaat-neeche, backed by a winning discourse, a popular base, connections with influential state officials, and a clearly charted yet expanding agenda with active fund flows. This is not to imply that the NGO has become all-powerful or that confrontations do not still occur (they do, especially with line department officials), but instead to highlight the combination of complementary resources that have greatly increased its capacity to act. While SPS has used its

\footnotetext{
${ }^{24}$ I use hegemony here not as a 'finished and monolithic ideological formation, but as a problematic, contested, political process of domination and struggle' (Roseberry 1994: 358). Following James Scott's influential observations of the social exercise of domination, it is possible to imagine that in each of these acts of domination, those 'victimised' did not necessarily believe in the 'superiority' of their exploiters, while adopting a more practical façade of compliance and passivity.

${ }^{25}$ Email communication with an SPS member.

${ }^{26}$ Refer to Phil Abrams for a powerful elucidation of 'state-idea', which is 'projected, purveyed, and variously believed in different societies in different times' (1988: 73).
} 
position to speak out in favour of subordinate interests until recently, it would be interesting to observe the kinds of issues it takes up in the future without compromising its own critical leverage. It would be equally important to understand the kinds of subject-positions that SPS is fostering as a hegemonic power in the area, amongst its supporters, employees as well as patrons.

\section{Conclusion: The nature and limits of NGO power}

In my attempt to understand the trajectory of SPS in ghaat-neeche, what became amply clear were the profound links between its roles as a political entrepreneur and an agent of development. SPS was aware of these linkages at the very outset, since it sought to act precisely to direct the state's attention and development resources to areas that were politically and economically marginalised. In its practical experience, it did not segregate the two roles, systematically exposing the politics of exploitation and orchestrating popular mobilisation, local awareness and state support to harness a new sort of politics in the region while acting as a formal agent of development for the state. Simultaneously, its own transformation from new, even subordinate actor to a dominant player in ghaat-neeche development and politics is an inescapable part of the story. So how are we to understand and appraise this NGO's praxis, and equally, its positioning within the spectrum of organisations that work at the grassroots?

Recent discussions of grassroots activity are increasingly recognising the blurred boundaries between resistance and acquiescence, struggle and compromise, activism and development, all binaries that have typically distinguished radical social movements from NGOs. Yet, it is far from easy for an organisation to retain all these aspects at the same time. Sangeeta Kamat writes about the difficulty of maintaining a balance between 'a struggle based organisation supported largely through popular participation and nominally paid tribal cadre on the one hand, and a development organisation flush with funds managed by a professional paid staff on the other' (2002: 77). Carrol Warren points to the complexity of 'transforming political activists into problem solving practitioners with mediation, facilitation and management skills' (2005: 66). In SPS's case, much of this transformation has been remarkably nuanced, mostly because it started out as an organisation with a philosophy of positive engagement with the state, invoking confrontation and cooperation in alternate measure. At the same time, one cannot help but wonder whether the more radical elements of its strategy would not be blotted out by the constraints of a newfound hegemony, and whether it is not already a dominant actor with its own imposition of subordination. My account offers some insight into perceptions of this NGO's manipulations to wield local power and popularity, especially amongst those piqued at it. 
While recognising these aspects, the kind of praxis described in this article perhaps offers a way forward to numerous NGOs that seek to forge change at the grassroots without being declared outlawed, or without rendering themselves unsustainable ${ }^{27}$. Similarly, there is reassurance in the fact that NGOs need not disband their state-related development activity in an effort to rearticulate a new politics. Moreover, their actions, like that of SPS as described here, can serve to explode the myth of depoliticisation of development, so widely entrenched within the international development machinery. In this respect too, SPS's experiences revealed that depoliticisation is neither a homogenous nor always a wilful discourse, equally subscribed to by a multitude of state actors at different levels. Local state officials in Bagli regularly revealed the small ' $p$ ' of development politics by openly allying with the locally dominant and engaging in individual acts of appropriation. While senior officials were more likely to preserve a technocratic façade to development policy formulation and implementation, they were also formally bound to the idea of the state as a guarantor of rights. It was precisely this disjuncture that allowed SPS to obtain their support to orchestrate development politics with a capital 'P'. These differences in the interests and stakes of state actors at various levels make it harder for a coherent representation of what constitutes the 'politics' that ought to be excluded from development, yielding unforeseen consequences. As in this case, NGOs working in development may find creative possibilities arising from such disjuncture in order to effect change.

SPS's experience cannot possibly be a blueprint for non-governmental action. This analysis has focused on very specific junctures in its life history that concretely shaped its trajectory. In deed, another NGO in another part of Dewas district at another time in history would be very likely to produce a very different story. But there are, in my opinion, some general lessons to be drawn about the power of NGOs and also the limitations to such power. The article will conclude with a brief delineation of NGO power as evident in the SPS story.

The first is the power to effect concrete changes in local power relations. Upon its entry into ghaat-neeche, SPS changed wage relations, overturned an exploitative anti-tribal coalition, and facilitated a material transformation in common property access. The second aspect of its power is that it is text-oriented. SPS relied on a correct reading of the laws of the Indian state as also official policy guidelines for the watershed programme to fuel its radical initiatives. This aspect is

\footnotetext{
${ }^{27}$ Here I use Kamat's definition of praxis to understand the NGO's 'relation to the state, its mobilisation of certain kinds of identities, the nature of its development activity and its relation to the development apparatus' (2002: 161).
} 
particularly important since NGOs do not have constitutional power. Therefore, there is a greater need for NGOs to justify their actions on the basis of existing law and state policy frameworks. Undoubtedly, many NGOs may wish to, and have, take (n) their roles beyond this to campaign for a change in laws and state policies.

The third aspect of NGO power is that it is performance oriented. During its early history, SPS repeatedly chose to create public events out of its confrontations, precisely to attract the attention of state actors and promote awareness of the issue at hand amongst local people. In contrast, state actors do not necessarily need to create public events in order to be effective. For example, the district collector could merely issue an order preventing passage through a road, and deploy police personnel to ensure obedience, without reference to a public debate. In contrast, there is no consensus or lawful validation of what power NGOs should have. Thus, NGOs frequently resort to public performance and available methods of publicity to make their point. More recently too, SPS continues to exercise power through performance in public settings. The jan-sunvaaryi is an appropriate instance where SPS performs its part as the champion of accountability in a popular assembly.

Finally, NGO power greatly depends on its ability to elicit government support. Critical steps like the land records camp could not have been taken without the support of senior government officers. In fact, SPS ultimately depended on state validation to acquit itself of the charges leveled against it by agitating sarpanches in 1995. More recently, SPS's agenda of networking with other grassroots organizations and panchayats is contingent on financial and procedural support extended by the Union and state governments.

SPS's case also illustrates that NGO power is not without limitations. For one, it can be exclusionary. NGOs are not state actors (though they might be closely aligned with the latter), and their process of acquiring local power is typically at the cost of existing power holders. This explains why so many NGOs are frequently drawn into antagonistic relationships with panchayats or local state officials. A later synergy between NGOs and other local actors may no doubt emerge, as it did in the case of SPS. Two, there are procedural issues involved in how power claimed by an NGO is described to others. This follows the previous point regarding the lack of any legal consensus or constitutional validation of what NGOs can do. Nevertheless, as this article as shown, NGOs, operating with appropriate political conditions, can be agents of 
development and political entrepreneurs; indeed, their capacity to be effective depends precisely on their ability to mesh these roles together.

\section{References}

Abrams, P. (1988), 'Notes on the Difficulty of Studying the State', Journal of Historical Sociology, Volume 1, no. 1, pp 58-89

Behar, A. (1999), 'Initiatives for Decentralisation of Governance in Madhya Pradesh', Economic and Political Weekly, November 6, www.epw.org.in

Behar, A. (2001), 'Madhya Pradesh: Gram Swaraj, Experiment in Direct Democracy', Economic and Political Weekly, Volume 36, no. 10, pp 823-826

Behar, A. and Kumar, Y. (2002), 'Decentralisation in Madhya Pradesh, India: From Panchayati Raj to Gram Swaraj (1995-2001)', Working Paper 170, Overseas Development Institute, London

Chhotray, V. (2004), 'The Negation of Politics in Participatory Watershed Development, Kurnool, Andhra Pradesh', Development and Change, Vol 35, no. 2, pp 327-356

Ferguson, J. (1990), The Anti-Politics Machine: "Development”, Depoliticisation and Bureaucratic Power in Lesotho, Cambridge University Press, Cambridge

Harriss, J. (2001), Depoliticising Development: The World Bank and Social Capital, Leftword, New Delhi

Garain, S. (1994), 'Government-NGO Interface in India: An Overview', Indian Journal of Social Work, Volume 55, no. 3, pp 337-346

Held, D. (1984), 'Central Perspectives on the State', in G. McLennan, D. Held and S. Hall (eds.), The Idea of the Modern State, Open University Press, Philadelphia, PA

Kamat, S. (2002), Development Hegemony: NGOs and the State in India, Oxford University Press, New Delhi

Kaviraj, S. and Khilnani, S. (2001) (eds.), Civil Society: History and Possibilities, Cambridge University Press, Cambridge

Igoe, J. (2003), 'Scaling up Civil Society: Donor Money, NGOs and Pastoralist Land Rights Movement in Tanzania', Development and Change, Volume 34, no. 5, pp 863-885

Pieterse, J. (1998), 'My Paradigm or Yours? Alternative Development, Post-Development, Reflexive Development', Development and Change, Volume 29, no. 2, pp 343-373

Roseberry, W. (1994), 'Hegemony and the Language of Contention', in G.M. Joseph and D. Nugent (1994) (eds.), Everyday Forms of State Formation: Revolution and the Negotiation of Rule in Mexico, Duke University Press, Durham and London 
Sen, S. (1999), 'Some Aspects of State-NGO Relationships in India in the Post-Independence Era', Development and Change, Volume 30, pp 327-355

Scott, J.C. (1990), Domination and the Arts of Resistance: Hidden Transcripts, Yale University Press, New Haven

Tideman, E.M. (1998), Watershed Management: Guidelines for Indian Conditions, Omega Scientific Publishers, New Delhi

Warren, C. (2005), 'Mapping Common Futures: Customary Communities, NGOs and the State in Indonesia's Reform Era', Development and Change, Vol 36, no. 1, pp 49-73 


\section{Appendix 1}

\section{Principal changes in land use}

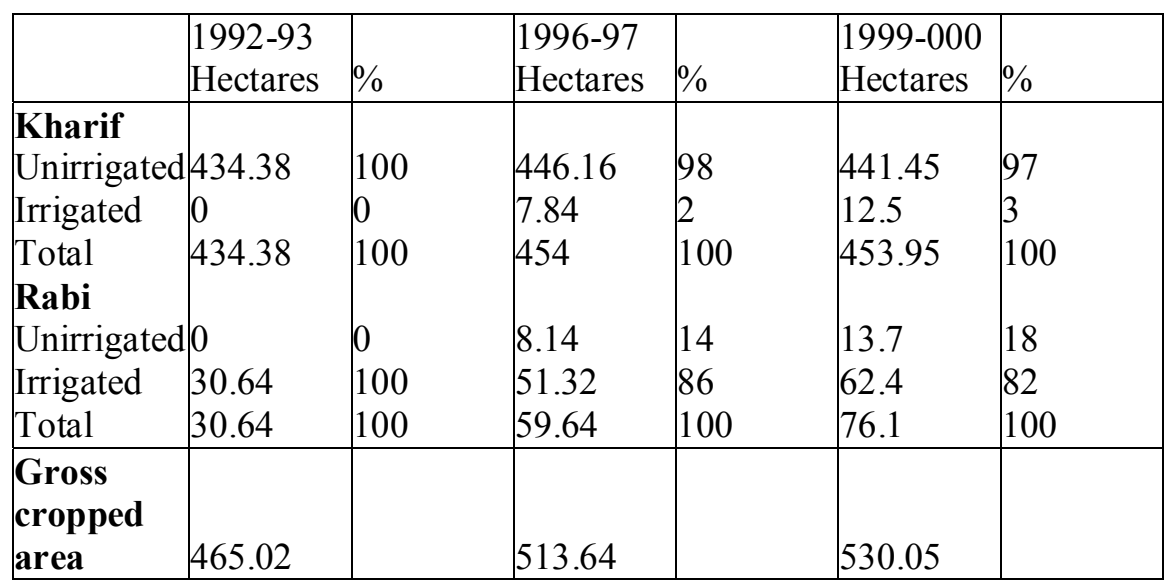

Source: Project records, Samaj Pragati Sahyog ${ }^{28}$

- Increase in gross cropped area from 465.02 ha in 1992-93 to 513.64 ha in 1996-97 and 530.05 in $1999-2000$

- Increase in cropped area in the kharif season from 434.38 ha in 1992-93 to 454 ha in 1996-97 and 453.95 ha in 1999-2000. Irrigated cultivation during the rainfed kharif season increased from 0 ha to 12.5 ha in 8 years

- Increase in cropped area in the rabi season from 30.64 ha in 1992-93 to 59.64 in 1996-97 and 76.1 in 1999-2000

${ }^{28}$ Although the project officially started in 1995 , we start considering changes since 1992, the year that SPS started working here. 1996-97 has been taken as a mid-point in this eight-year period under consideration. 